\title{
PERLINDUNGAN HUKUM TERHADAP KREDITUR DALAM HAL DIBATALKANNYA SERTIFIKAT HAK GUNA BANGUNAN YANG DIBEBANI HAK TANGGUNGAN \\ (Studi Kasus Perkara Perdata Nomor: 27/PDT.G/2010/PN.PDG
}

\author{
Oleh: \\ Rage Cikal Nugroho \\ Email: ragecikalnugroho@gmail.com \\ Fakultas Hukum Universitas Andalas
}

\begin{abstract}
ABSTRAK
Dunia perbankan memiliki peran penting dalam menunjang perkonomian masyarakat saat ini salah satunya adalah dengan adanya fasilitas kredit sebagai kekuatan utama dalam menggerakan roda perekonomian saat ini. Namun dalam implementasinya, pihak bank harus terlebih dahulu menerapkan prinsip kehatihatian dalam memberikan fasilitas kredit, salah satunya adalah dengan adanya agunan sebagai suatu jaminan pelunasan hutang apabila debitur wanprestasi. Salah satu bentuk agunan itu adalah dengan Hak Tanggungan. Permasalahan muncul apabila objek dari Hak Tanggungan tersebut kemudian menjadi sengketa di Pengadilan sampai akhirnya objek Hak Tanggungan yaitu Hak Guna Bangunan dibatalkan oleh Pengadilan Negeri. Metode yang digunakan adalah pendekatan normatif. Upaya hukum setelah dibatalkannya sertifikat Hak Guna Bangunan adalah mediasi oleh debitur dan kreditur untuk pemberian jaminan kebendaan baru atau dengan borgtoch serta dapat juga dengan gugatan perdata ke Pengadilan oleh pihak bank atas perbuatan melawan hukum yang dilakukan oleh Kantor Pertanahan Kota Padang. Hubungan hukum antara kreditur dengan debitur tetap terikat pada perjanjian pokok yaitu perjanjian kredit itu sendiri, akan tetapi kedudukan kreditur berubah dari kreditur preferen menjadi kreditur konkuren. Bentuk perlindungan hukum yang diberikan adalah perlindungan hukum refresif karena bertujuan untuk menyelesaikan sengketa antara kreditur dengan debitur jika terjadi kredit bermasalah.
\end{abstract}

Kata Kunci: Kredit, Hak Tanggungan, Hak Guna Bangunan.

\section{ABSTRACT}

Nowadays, banking institutions possess crucial roles to support the economy. One of the roles is to provide credit facilities as an important generator of national economy. Before delivering the funds, the banks must apply the prudential principles, such as collaterals, to recover the damages while the debt is in default. The writer considers that the bank could accept the mortgage as a collateral. However, there is a legal issue while the object of mortgage is brought into a legal dispute examined by courts. In this paper, the writer uses normative approach. Furthermore, if the building rights on land-based ownership was annulled, the debtor and creditor could bring it into mediation in order to have a 
new mortgage. Besides, the parties could also proceed it in civil courts for an unlawful act committed by the public officer at Padang Land Agency. Although there is a shift of creditor's position, from preferred creditor to concurrent one, the contract still remains. In this point, the legal instruments give both parties a set of dispute settlements for this issue.

Keywords: credit, mortgage rights, building rights on land.

\section{PENDAHULUAN}

Untuk menunjang kehidupan ekonomi yang semakin kompleks, kegiatan pinjam-meminjam uang telah dilakukan sejak lama dalam kehidupan masyarakat yang telah mengenal uang sebagai pembayaran. Dapat diketahui bahwa hampir semua masyarakat telah menjadikan kegiatan pinjam-meminjam uang sebagai sesuatu yang sangat diperlukan untuk mendukung perkembangan kegiatan perekonomiannya dan untuk meningkatkan taraf kehidupannya. Saat ini, berbagai lembaga keuangan terutama bank konvensional, telah membantu pemenuhan kebutuhan dana bagi kegiatan perekonomian dengan memberikan pinjaman uang antara lain dalam bentuk kredit perbankan. Kredit perbankan merupakan salah satu usaha bank konvensional yang telah banyak dimanfaatkan oleh anggota masyarakat yang memerlukan dana.

Pasal 1 angka 2 Undang-Undang Nomor 7 Tahun 1992 tentang Perbankan sebagaimana telah diubah dengan Undang-Undang Nomor 10 Tahun 1998 (selanjutnya disingkat UU Perbankan) menyebutkan bahwa bank merupakan badan usaha yang menghimpun dana dari masyarakat dalam bentuk simpanan dan menyalurkannya kepada masyarakat dalam bentuk kredit dan atau bentuk-bentuk lainnya dalam rangka meningkatkan taraf hidup rakyat banyak. Pada kegiatan pinjam-meminjam uang yang terjadi di masyarakat dapat diperhatikan bahwa umumnya sering dipersyaratkan adanya penyerahan jaminan utang oleh pihak peminjam kepada pihak pemberi pinjaman. Jaminan utang tersebut dapat berupa barang (benda) sehingga merupakan jaminan yang memeberikan hak kebendaan kepada pemegang jaminan. ${ }^{1}$

Pada prinsipnya tidak semua benda jaminan dapat dijaminkan pada lembaga perbankan atau lembaga keuangan nonbank, namun benda yang dapat

1 M. Bahsan, 2007, Hukum Jaminan dan Jaminan Kredit Perbankan Indonesia, PT. Rajagrafindo Persada Jakarta, hlm. 1-2. 
dijaminkan adalah benda-benda yang memenuhi syarat-syarat tertentu. Syarat benda jaminan yang baik adalah dapat secara mudah membantu perolehan kredit itu oleh pihak yang memerlukannya, tidak melemahkan potensi (kekuatan) si pencari kredit untuk melakukan atau meneruskan usahanya dan memberikan kepastian kepada si kreditur, dalam arti bahwa barang jaminan setiap waktu tersedia untuk dieksekusi bila perlu dapat mudah diuangkan untuk melunasi hutangnya sipenerima kredit. ${ }^{2}$

Berkenaan dengan perkembangan di masyarakat, hak atas tanah menjadi primadona sebagai suatu kebendaan yang bernilai tinggi, sehingga pada realitanya kegiatan pinjam-meminjam uang pada bank konvensional tidak menutup kemungkinan menjadikan hak atas tanah sebagai jaminan kebendaan atas utang. Tanah merupakan peranan yang besar dari dinamika pembangunan, maka di dalam Pasal 33 ayat (3) UUD 1945 dinyatakan bahwa Bumi, air dan kekayaan alam yang terkandung didalamnya dikuasai oleh Negara dan dipergunakan sebesar-besarnya untuk kemakmuran rakyat. ${ }^{3}$ Tanah ini kemudian diberikan kepada dan dipunyai oleh orang dengan hak-hak yang disediakan Negara berdasarkan Undang-Undang Nomor 5 Tahun 1960 tentang Peraturan PokokPokok Agraria (selanjutnya disingkat UUPA). ${ }^{4}$

Lembaga jaminan yang mengatur mengenai tanah pada mulanya dikenal sebagai hipotek yang mana diatur dalam Pasal 1162 sampai dengan Pasal 1232 Kitab Undang-Undang Hukum Perdata (Selanjutnya disingkat KUHPerdata), ${ }^{5}$ akan tetapi janji yang diberikan dalam Pasal 51 UUPA yang mana sudah diadakan atau disediakan suatu lembaga hak jaminan yang kuat yang dapat dibebankan pada hak atas tanah yaitu dinamakan dengan Hak Tanggungan. ${ }^{6}$ Namun hal tersebut harus menunggu selama 34 tahun sejak lahirnya UUPA, dan barulah lahir Undang-undang tentang Hak Tanggungan pada tanggal 9 April 1996 yaitu Undang-Undang Nomor 4 Tahun 1996 tentang Hak Tanggungan atas Tanah

${ }^{2}$ Subekti dalam buku Salim HS, 2004, Perkembangan Hukum Jaminan di Indonesiai, PT. Rajagrafindo Persada, Jakarta, hlm. 27. 47.

${ }^{3}$ Urip Santoso, 2010, Pendaftaran dan Peralihan Hak atas Tanah, Kencana, Jakarta, hlm.

${ }^{4}$ Boedi Harsono, 2005, Hukum Agraria Indonesia (Sejarah Pembentukan Undang-Undang Pokok Agraria, Isi dan Pelaksanaannya), Djambatan, Jakarta, hlm. 18.

${ }^{5}$ M. Bahsan, Op, cit, hlm. 14.

${ }^{6}$ Rachmadi Usman, 2008, Hukum Jaminan Keperdataan, Sinar Grafika, Jakarta, hlm. 244. 
Beserta Benda-Benda yang Berkaitan dengan Tanah (selanjutnya disingkat UUHT). ${ }^{7}$

Pasal 4 UUHT menyatakan, hak atas tanah yang dapat dibebani dengan hak tanggungan antara lain yaitu Hak Milik, Hak Guna Usaha, Hak Guna Bangunan dan Hak Pakai atas tanah Negara yang menurut ketentuan yang berlaku wajib didaftar dan menurut sifatnya dapat dipindahtangankan. Sehingga hubungan ataupun kaitannya dengan kredit perbankan adalah dimana hak-hak atas tanah menjadi suatu jaminan pelunasan hutang debitur yang difasilitasi oleh lembaga jaminan yang bernama Hak Tanggungan dan untuk pembebanan jaminan hak tanggungan tersebut tentunya pihak kreditur dalam hal ini bank konvensional bertindak atas dasar bukti kepemilikan sah yaitu berupa sertifikat hak atas tanah.

Pemberian kredit oleh bank kepada debitur tidak serta merta dilangsungkan dengan begitu saja, namun ada suatu standar yang dibuat dalam hal prosedur pemberian kredit, baik dari sisi fit and propertest atau penilaian terhadap nasabah sebagai calon debitur maupun melakukan tindakan due diligence ${ }^{8}$ (investigasi uji tes) kepada calon debitur terhadap fasilitas kredit yang akan diberikan, apakah nantinya calon debitur ini memenuhi kriteria yang ditentukan oleh bank atau tidak. Kesemuanya itu yakni merupakan prinsip kehati-hatian yang dipegang oleh pihak bank, sebagaimana dalam Pasal 2 UU Perbankan disebutkan bahwa perbankan Indonesia dalam melakukan usahanya berdasarkan demokrasi ekonomi dengan menggunakan prinsip kehati-hatian.

Lebih lanjut juga disebutkan dalam Pasal 29 Ayat (2) UU Perbankan bahwa Bank wajib memelihara tingkat kesehatan bank sesuai dengan ketentuan kecukupan modal, kualitas aset, kualitas manajemen, likuiditas, rentabilitas, solvabilitas, dan aspek lain yang berhubungan dengan usaha bank, dan wajib melakukan kegiatan usaha sesuai dengan prinsip kehati-hatian. Hal tersebut menjelaskan bahwa dalam pemberian kredit haruslah menggunakan prinsip

\footnotetext{
${ }^{7}$ Adrian Sutedi, 2012, Hukum Hak Tanggungan, Sinar Grafika, Cetakan Kedua, Jakarta, hlm. 1.

${ }^{8}$ Due diligence atau uji tuntas adalah istilah yang digunakan untuk penyelidikan penilaian kinerja perusahaan atau seseorang, ataupun kinerja dari suatu kegiatan guna memenuhi standar baku yang ditetapkan. Dikutip dari http://id.wikipedia.org/uji_tuntas, diakses pada tanggal 30 Januari 2016 pukul 10.30 WIB.
} 
kehati-hatian untuk mengurangi resiko kerugian yang akan timbul agar keadaan ekonomi bank tetap sehat.

Secara implementasi dikehidupan bermasyarakat, terjadi begitu banyak permasalahan-permasalahan hukum yang timbul baik dari kegiatan pemberian kredit hingga permasalahan yang muncul dari hak tanggungan itu sendiri yang menjadi jaminan dari perjanjian kredit. Dalam kredit bisa dilihat berbagai macam permasalahan hukum yang muncul mulai dari kredit bermasalah seperti kredit bermasalah atau terjadinya wanprestasi dari debitur, juga bisa saja dari pihak perbankan yang bermasalah terhadap kesalahan-kesalahan yang timbul dalam pemberian kredit. Dalam konteks debitur wanprestasi, sudah sangat jelas diatur dalam UUHT bahwa apabila debitur tidak dapat melunasi hutang-hutangnya maka kreditur diberi hak preferen untuk mengeksekusi jaminan sebagai pelunasan hutang-hutang debitur melalui pelelangan umum. Permasalahan lain juga bisa terjadi apabila objek hak tanggungan yang menjadi jaminan dari perjanjian kredit itu tiba-tiba musnah atau hilang haknya oleh hukum ataupun menjadi sengketa di Pengadilan. Dalam hal ini penulis lebih berkonsentrasi pada permasalahan yang menyangkut mengenai objek jaminan hak tanggungan itu sendiri yaitu Hak Guna Bangunan.

Bank Nagari secara yuridis dalam memberikan fasilitas kredit terhadap perkara kasus tersebut pada prinsipnya telah memenuhi syarat-syarat dan prinsipprinsip yang merupakan ketentuan dari pihak Bank itu sendiri. Di sisi lain juga debitur dalam memenuhi ketentuan pengajuan kredit telah sesuai dengan syarat yang diberikan oleh pihak Bank, baik dari syarat-syarat notariil maupun berupa asas-asas serta prinsip-prinsip dari Bank. Persoalan kemudian timbul bahwa kemudian sertifikat Hak Guna Bangunan yang dijadikan sebagai jaminan hak tanggungan untuk pelunasan kredit tersebut dibatalkan oleh hakim, dimana pertimbangan hakim dalam putusan perkara tersebut yaitu bahwa tergugat (debitur) dalam membeli hak guna bangunan ini terlebih dahulu telah mengecek tanah tersebut pada Kantor Pertanahan Kota Padang dan tidak masalah serta dalam keadaan aman tidak ada dalam sengketa, sehingga tergugat adalah pembeli atau pemilik hak dengan itikad baik. 
Kemudian, bahwa Hak Guna Bangunan tersebut dimohonkan atas tanah Negara bekas Eigendom Vervonding dengan sesuai ketentuan dari Badan Pertanahan Nasional hingga dikeluarkannya sertifikat Hak Guna Bangunan tersebut dan setelah kemudian dicek oleh penggugat dengan tanah hak miliknya bahwa ternyata memang terjadi tumpang tindih (overlap), sehingga menurut majelis kesalahan ini terjadi karena kelalaian dari Kantor Pertanahan Kota Padang yang kurang teliti dalam penanganan administrasi tanah sehingga terjadi tumpang tindih kepemilikan. Pada amar putusannya sertifikat Hak Guna Bangunan tersebut kemudian dibatalkan oleh majelis hakim dan telah memiliki kekuatan hukum yang tetap.

Terhadap kasus ini, Bank Nagari dan Kantor Pertanahan Kota Padang tentu menimbulkan keterkaitan dalam permasalahan hukum, dimana akibat kelalaian dari pihak Kantor Pertanahan Kota Padang yang menerbitkan sertifikat Hak Guna Bangunan Nomor 209 atas nama Buchari, memberikan dampak hukum serta menyebabkan adanya potensi timbulnya kerugian bagi pihak Bank khususnya hilangnya hak preferent terhadap objek yang menjadi hak tanggungan. Jika hal tersebut terjadi, bagaimana perlindungan hak pihak Bank sebagai kreditur yang secara langsung dirugikan terhadap kelalaian dari pihak Kantor Pertanahan Kota Padang yang merupakan suatu badan Tata Usaha Negara, dalam hal itu perbuatan atau tindakan dari Kantor Pertanahan Kota Padang dapat dikategorikan sebagai perbuatan melawan hukum.

Pasal 1365 KUHPerdata disebutkan bahwa tiap perbuatan melanggar hukum, yang membawa kerugian kepada seorang lain, mewajibkan orang yang karena salahnya menerbitkan kerugian itu, mengganti kerugian itu. Sehingga harus ada upaya hukum yang dilakukan oleh Bank Nagari selaku kreditur dalam menuntut hak atas tindakan kesewenang-wenangan pihak Kantor Pertanahan Kota Padang yang salah dalam menerbitkan Sertifikat Hak Guna Bangunan tersebut serta upaya yang dilakukan pihak Bank selaku kreditur dalam hubungan hukumnya terhadap debitur sebagai pemilik Hak Guna Bangunan yang dibatalkan oleh Pengadilan Negeri. 


\section{RUMUSAN MASALAH}

Berdasarkan uraian diatas dapat dirumuskan permasalahan sebagai berikut:

1. Apa upaya hukum yang dapat dilakukan kreditur dalam mengantisipasi terjadinya resiko terhadap agunan jika terjadi kredit bermasalah?

2. Bagaimanakah hubungan hukum antara kreditur dan debitur setelah dibatalkannya sertifikat hak guna bangunan yang dijadikan jaminan hak tanggungan?

3. Bagaimanakah perlindungan hukum terhadap kreditur setelah Putusan Pengadilan Negeri Kelas I A Padang dengan perkara Nomor: 27/PDT.G/2010/PN.PDG yang membatalkan sertifikat hak guna bangunan yang dibebani hak tanggungan?

\section{KERANGKA KONSEPTUAL}

1. Perlindungan Hukum

Perlindungan hukum yaitu upaya atau bentuk pelayanan yang diberikan oleh hukum kepada subjek hukum serta hal-hal yang menjadi objek yang dilindungi. Sedangkan teori tentang perlindungan hukum itu sendiri merupakan teori yang mengkaji dan menganalisis tentang wujud atau bentuk atau tujuan dari perlindungan subjek hukum yang dilindungi serta objek perlindungan yang diberikan oleh hukum kepada subjeknya. ${ }^{9}$

Satjipto Rahardjo berpendapat bahwa perlindungan hukum memberikan pengayoman terhadap hak asasi manusia yang dirugikan orang lain dan perlindungan itu diberikan kepada masyarakat agar dapat menikmati semua hak-hak yang diberikan oleh hukum. ${ }^{10}$

2. Kreditur

Kreditur adalah pihak (perorangan, organisasi, perusahaan atau pemerintah) yang memiliki tagihan kepada pihak lain (pihak kedua) atas property atau layanan jasa yang diberikannya (biasanya dalam bentuk kontrak atau perjanjian) dimana diperjanjikan bahwa pihak kedua tersebut akan mengembalikan properti yang nilainya sama atau jasa. Pihak kedua

\footnotetext{
${ }^{9}$ Salim HS dan Erlies Septiana Nurhani, 2013,Penerapan Teori Hukum Pada Penelitian Tesis dan Desertasi, PT. Rajagrafindo Persada, Jakarta, hlm. 262.

${ }^{10}$ Satjipto Rahardjo, 2000, Ilmu Hukum, PT. Citra Aditya Bakti, Bandung, hlm. 54.
} 
disebut sebagai peminjam atau yang berutang. ${ }^{11}$ Kreditur dalam penelitian ini adalah Bank.

3. Hak Tanggungan

Hak tanggungan menurut Pasal 1 angka 1 UUHT adalah hak jaminan yang dibebankan pada hak atas tanah sebagaimana dimaksud dalam Undang-Undang Nomor 5 Tahun 1960 tentang peraturan dasar pokokpokok agrarian, berikut atau tidak berikut benda-benda lain yang merupakan satu kesatuan dengan tanah itu, untuk pelunasan utang tertentu yang memberikan kedudukan yang diutamakan kepada kreditor tertentu terhadap kreditor-kreditor lain.

4. Sertifikat

Sertifikat menurut surat tanda bukti hak sebagaimana dimaksud dalam Pasal 19 ayat (2) huruf c UUPA untuk hak atas tanah, hak pengelolaan, tanah wakaf, hak milik atas satuan rumah susun dan hak tanggungan yang masing-masing sudah dibukukan dalam buku tanah yang bersangkutan. Sertifikat tanah adalah buku tanah dan surat ukur yang dijadikan dalam satu buku dan disampul (dengan sampul luar berwarna hijau dan menggunakan kertas berukuran kwarto), kemudian menjadi sebuah dokumen yang diberikan judul yaitu "SERTIFIKAT". ${ }^{12}$

\section{METODE PENELITIAN}

Untuk dapat menjawab permasalahan yang terdapat dalam penulisan proposal ini, maka dilakukan suatu penelitian guna melengkapi data yang harus diperoleh untuk dipertanggungjawabkan kebenarannya yang akan dijadikan sebagai bahan penulisan dan jawaban yang objektif. Maka metode penelitian yang dipakai adalah :

\section{Pendekatan dan Sifat Penelitian}

Metode penelitian yang digunakan adalah metode penelitian hukum Normatif, dimana penelitian ini menekankan kepada norma-norma hukum

11 Dikutip dari situs https://id.wikipedia.org/wiki/kreditur, diakses pada tanggal 20 Desember 2015, Pukul 22.00 WIB.

${ }^{12}$ Eli Wuria Dewi, 2014, Mudahnya Mengurus Sertifikat Tanah \& Segala Perizinannya, Buku Pintar, Yogyakarta, hlm. 44. 
yang bertujuan untuk mempelajari satu atau beberapa gejala hukum tertentu.

Penelitian ini bersifat deskriptif analitis, yaitu penelitian yang menggambarkan serta menjelaskan suatu keadaan yang diperoleh melalui penelitian di lapangan dan kemudian dianalisis lebih dalam menggunakan teori-teori yang relevan.

\section{Sumber dan Jenis Data}

Sumber dan jenis data yang digunakan di dalam penelitian ini adalah data sekunder yaitu meliputi:

a) Bahan Hukum Primer, yaitu bahan hukum yang mempunyai kekuatan hukum mengikat bagi setiap individu atau masyarakat yang berupa produk-produk hukum atau ketentuan-ketentuan peraturan perundang-undangan.

b) Bahan Hukum Sekunder, yaitu bahan hukum yang erat kaitannya dengan bahan hukum primer, yang dapat membantu menjelaskan maupun menganalisis bahan hukum primer antara lain hasil penelitian, buku-buku hukum, karya tulis dari ahli hukum, yang berkaitan dengan permasalahan yang diteliti.

\section{Alat Pengumpulan Data}

Dalam pengumpulan data yang dilakukan adalah Studi dokumen, yaitu dengan mempelajari dokumen-dokumen berupa data tertulis mengenai masalah yang diteliti.

\section{Pengolahan dan Analisis Data}

Data yang telah diperoleh diolah dengan cara Editing, yaitu data yang telah diperoleh tidak semuanya dimasukkan ke dalam hasil penelitian, namun dipilih terlebih dahulu data yang berkaitan dengan permasalahan yang diteliti, sehingga diperoleh data yang lebih terstruktur. Data yang diolah, kemudian dianalisis secara kualitatif, yaitu analisis terhadap datadata untuk menghasilkan data yang tersusun secara sistematis berdasarkan peraturan perundang-undangan, pandangan para ahli dan pengalaman peneliti. 


\section{PEMBAHASAN}

\section{Upaya Hukum Dalam Mengantisipasi Terjadinya Resiko Terhadap Agunan Jika Terjadi Kredit Bermasalah}

Bank dalam memberikan kredit kepada calon nasabah haruslah memegang prinsip-prinsip kehati-hatian, sebagaimana dalam Pasal 2 UU Perbankan disebutkan bahwa perbankan Indonesia dalam melakukan usahanya berdasarkan demokrasi ekonomi dengan menggunakan prinsip kehati-hatian. Lebih lanjut juga disebutkan dalam Pasal 29 Ayat (2) UU Perbankan bahwa Bank wajib memelihara tingkat kesehatan bank sesuai dengan ketentuan kecukupan modal, kualitas aset, kualitas manajemen, likuiditas, rentabilitas, solvabilitas, dan aspek lain yang berhubungan dengan usaha bank, dan wajib melakukan kegiatan usaha sesuai dengan prinsip kehati-hatian. Hal ini didasarkan karena risiko yang sangat tinggi dalam melakukan pemberian kredit sebagai usaha utama bank. Selain itu kegagalan di bidang kredit dapat berakibat pada terpengaruhnya kesehatan dan kelangsungan usaha bank sendiri.

Pada Pasal 8 Ayat (1) UU Perbankan menyebutkan bahwa:

(1)Dalam memberikan kredit atau pembiayaan berdasarkan Prinsip Syariah, Bank Umum wajib mempunyai keyakinan berdasarkan analisis yang mendalam atas itikad dan kemampuan serta kesanggupan Nasabah Debitur untuk melunasi utangnya atau mengembalikan pembiayaan dimaksud sesuai dengan yang diperjanjikan.

Pasal 8 Ayat (1) diatas memberikan artian bahwa sebelum memberikan kredit bank harus melakukan penilaian seksama, mengingat sumber dana kredit yang disalurkan adalah bukan dana dari bank itu sendiri melainkan dana yang berasal dari masyarakat sehingga perlu untuk dilakukan penerapan prinsip kehatihatian melalui analisa yang mendalam, penyaluran yang tepat, pengawasan dan pemantauan yang baik, perjanjian yang sah dan memenuhi syarat hukum, pengikatan jaminan yang kuat dan dokumentasi perkreditan yang teratur dan lengkap, semua itu bertujuan agar kredit yang disalurkan tersebut dapat kembali tepat pada waktunya sesuai perjanjian kredit yang meliputi pinjaman pokok dan bunga.

Dalam praktik perbankan hal-hal yang dapat mendukung debitur dalam mendapatkan kredit adalah bagaimana cara calon debitur harus dapat meyakinkan calon krediturnya untuk mau memberikan pinjaman. Seorang debitur haruslah 
merupakan seorang yang bankable, yang dimana bankable ini dapat dilihat dari beberapa sisi. Hal ini berfungsi untuk mencegah terjadinya kredit bermasalah di kemudian hari, penilaian bank untuk memberikan persetujuan terhadap suatu permohonan kredit dilakukan dengan prinsip kehati-hatian yang terdiri dari 5C ini yang merupakan prinsip yang perlu dicermati oleh kreditur untuk melindungi diri dari risiko perbankan. ${ }^{13}$ Prinsip $5 \mathrm{C}$ itu adalah: ${ }^{14}$

1. Character, merupakan sifat atau watak seseorang. Sifat dan watak dari orang-orang yang akan diberikan kredit benar-benar harus dapat dipercaya.

2. Capacity, yaitu analisis untuk mengetahui kemampuan nasabah dalam membayar kredit. Kemampuan ini bisa telihat dari bagaimana nasabah mengelola bisnis, latarbelakang pekerjaan dan pendidikan.

3. Capital, untuk melihat penggunaan modal efektif atau tidak dapat dilihat dari laporan keuangan calon penerima kredit.

4. Condition, dalam menilai kredit hendaknya juga dinilai kondisi ekonomi, social dan politik yang ada sekaarang dan diprediksi untuk dimasa yang akan datang.

5. Collateral, merupakan jaminan yang diberikan oleh calon nasabah baik yang bersifat fisik maupun nonfisik. Jaminan hendaknya melebihi jumlah kredit yang diberikan. Jaminan harus juga diteliti keabsahan dan kesempurnaannya sehingga jika terjadi suatu masalah, maka jaminan yang dititipkan akan dapat dipergunakan secepat mungkin.

Dalam hal sertifikat Hak Guna Bangunan yang menjadi objek Hak Tanggungan dari suatu kredit, maka hal ini tentu memberikan hak istimewa kepada kreditur dalam hal jika terjadi wanprestasi maka kreditur memiliki hak eksekutorial terhadap eksekusi jaminan yang menjadi objek Hak Tanggungan tersebut. Oleh sebab itu, hak istimewa yang dimiliki oleh Bank terhadap jaminan berupa Hak Tanggungan dalam hal kredit ini merupakan senjata pamungkas suatu bank dalam mengantisipasi kerugian serta resiko terberat dalam pelaksanaan kredit yaitu jika terjadinya kredit bermasalah.

13 Dikutip dari situs http://www.landasanteori.com/2015/10/pengertian-prinsip-kehatihatian-dalam.html, diakses pada tanggal 09 April 2016 pada Pukul 10.30 WIB.

${ }^{14}$ Kasmir, Op. cit. 136-138. 
Dengan berdasarkan prinsip kehati-hatian yang dipegang teguh oleh bank, tentu memberikan pengertian bahwa bank jangan sampai mengalami kerugian ataupun timbulnya suatu resiko dalam kredit. Walaupun resiko bank terhadap kredit bermasalah tetap terjadi dalam dunia perbankan di Indonesia. Sehingga dengan adanya agunan dalam bentuk Hak Tanggungan memberikan keyakinan terhadap kegiatan bank yang jika adanya suatu jaminan akan mengatasi dan meminimalisir resiko yang ada.

Namun, berkaca dalam kasus diatas bahwa jaminan Hak Tanggungan yang berupa suatu hak atas tanah dalam hal ini Hak Guna Bangunan tidak menutup kemungkinan akan hapus haknya. Artinya perlu upaya hukum yang ditempuh pihak bank dalam mengantisipasi hilang atau musnahnya agunan yang menjadi jaminan pelunasan kredit selain dari pada penerapan prinsip 5C tersebut. Untuk mengurangi risiko dan menjamin kepentingan bank terhadap kredit-kredit yang akan dan/atau telah dikeluarkan, pemberian kredit harus di cover dengan jaminan yang cukup dan diasuransikan sesuai dengan ketentuan yang berlaku.

Asuransi sendiri pada dasarnya suatu perjanjian seorang penanggung dengan tertanggung dengan menerima uang premi untuk memberikan penggantian kepadanya karena suatu kerugian, kerusakan atau kehilangan keuntungan yang diharapkan yang mungkin akan didenda karena suatu peristiwa tersebut. Lebih lanjut Haminah mengatakan bahwa sebagai wujud adanya prinsip kehati-hatian bank dalam menjalankan usaha bank, bank memerlukan adanya jaminan bagi calon nasabahnya, dalam arti bahwa jaminan tersebut mempunyai fungsi yang sangat penting bagi bank, adanya jaminan kreditur dapat memberikan rasa aman dan kepastian hukum bahwa kredit yang diberikan dapat diperoleh kembali tepat pada waktunya. ${ }^{15}$

Untuk melaksanakan prinsip kehati-hatian maka pihak bank menutup atau mengadakan perjanjian lainnya yakni perjanjian asuransi dengan tujuan terjadinya resiko atau adanya ketidakmampuan nasabah menutup utang-utangnya, maka lembaga asuransi dapat dijadikan penjamin atas usaha mengatasi resiko yang akan

\footnotetext{
${ }^{15}$ Kutipan Wawancara "Haminah, staf pada Bagian Kredit Bank Nagari Cabang Pasar Raya Padang, hari senin, tanggal 1 September 2014”, dalam tesis Satri Taufik, 2015, Penyelesaian Klaim Asuransi Agunan Kredit Nasabah Pada Bank Nagari Sumatera Barat Cabang Pasar Raya, Universitas Andalas, hlm. 77.
} 
terjadi tersebut. Demikian juga terhadap agunan kredit yang dimungkinkan terjadi resiko terhadap musnahnya objek Hak Tanggungan, maka pihak bank dapat mengajukan klaimnya kepada pihak asuransi. Pihak asuransi dalam pelaksanaan pembayaran klaim yang diajukan juga mengikatkan dirinya dengan pihak tertanggung melalui suatu perjanjian yang diadakan sebelumnya.

Dalam dunia usaha, asuransi memegang peranan penting, yaitu memberikan perlindungan terhadap pengusaha/usahawan dari bahaya-bahaya datangnya diluar dugaan (gempa bumi, kebakaran, pemogokan, kapal tenggelam, pesawat terbang jatuh, dan lain-lain), dipihak lain perusahaan asuransi bisa melangsungkan hidupnya melalui premi yang diterima dari tertanggung. ${ }^{16}$ Dalam praktek asuransi oleh bank saat ini, ada dua jenis asuransi yang selalu dilakukan yaitu asuransi jiwa (perorangan) dan asuransi barang jaminan kredit: ${ }^{17}$

1. Asuransi jiwa debitur, tentang asuransi jiwa debitur, berdasarkan pengalaman bank, meninggalnya penerima kredit merupakan salah satu sebab yang dapat menimbulkan kesulitan dalam pengembalian kredit.

2. Asuransi barang jaminan kredit, asuransi ini merupakan asuransi barang jaminan yang banyak dipergunakan bank yaitu dengan jenis asuransi kerugian yang terdiri dari asuransi kebakaran, asuransi kendaraan bermotor dan asuransi angkutan laut, baik asuransi atas kapalnya maupun atas muatannya.

Pembahasan asuransi yang ada kaitannya dengan dunia perbankan, lebih dititikberatkan pada pembahasan asuransi jaminan kredit yang merupakan bidang asuransi kerugian (generasi insurance) yang meliputi jenis-jenis asuransi: ${ }^{18}$

1. Kebakaran (fire);

Definisi kebakaran dalam KUHD Bab V Pasal 287 s/d 308. Walaupun mengatur tentang kebakaran, tetapi tidak memberikan definisi secara jelas. Menurut Cole dalam bukunya Low of Fire Insurance yang memberikan definisi kebakaran sebagai sesuatu yang terbakar, yang seharusnya tidak terbakar, sifatnya sekonyong-konyong, atau merupakan

\footnotetext{
16 Thomas Suyatno, dkk, 2003, Kelembagaan Perbankan, PT. Gramedia Pustaka Utama, Edisi Ketiga, Jakarta, hlm. 89.

${ }^{17}$ H. R. Daeng Naja, Op. cit, hlm. 405

${ }^{18}$ Thomas Suyatno, dkk, Op. cit, hlm. 87.
} 
sesuatu kecelakaan atau tidak dapat diduga sebelumnya. ${ }^{19}$ T.R Smith CHR dan Francis dalam bukunya Fire Insurance Theory and Practise mengemukakan 3 patokan tentang asuransi kebakaran sebagai berikut: ${ }^{20}$

1) Harus ada nyala api secara nyata;

2) Kebakaran yang dapat dipertanggungkan harus bersifat mendadak;

3) Harus ada sesuatu yang terbakar yang seharusnya tidak terbakar.

2. Pengangkutan laut (Marine);

3. Kendaraan bermotor (motor vehicle).

Dari penjelasan diatas telah disebutkan bahwa dalam praktiknya terdapat dua jenis asuransi dalam hal pemberian kredit oleh bank. Pilihan yang pertama adalah asuransi jiwa debitur yakni apabila debitur meninggal dunia dan mengakibatkan tidak dapat dilunasinya kredit tersebut maka pihak asuransi yang membayar sisa kredit kepada pihak bank, kemudian pilihan kedua adalah asuransi barang jaminan kredit, dalam hal ini yang dijadikan objek asuransi adalah barang yang dijadikan jaminan atas kredit yang diberikan tersebut, contoh Hak Guna Bangunan yang menjadi Hak Tanggunganlah yang dijadikan jaminan asuransinya dengan perusahaan asuransi menanggung resiko berupa kebakaran, kendaraan bermotor, dan angkutan laut.

Pada kasus perdata terhadap putusan pengadilan diatas diketahui bahwa Hak Guna Bangunan yang dijadikan objek Hak Tanggungan pada Bank Nagari telah dibatalkan dengan tidak mempunyai kekuatan hukum hak nya sehingga jika kita lihat dalam kriteria resiko yang ditanggung oleh perusahaan asuransi dalam bidang kredit maka tidak termasuk kedalam resiko yang ditanggung. Sehingga jika memang sebelumnya Hak Guna Bangunan tersebut telah diasuransikan, maka resiko yang ditanggung hanya sebatas resiko kebakaran saja. Sedangkan dalam kasus ini Hak Guna Bangunan tersebut hak nya hapus dikarenakan adanya putusan pengadilan yang mana tidak dapat disamakan dengan adanya peristiwa kebakaran yang menurut T.R Smith CHR dan Francis dalam bukunya Fire Insurance Theory and Practise unsur dari adanya kebakaran itu ialah harus ada nyala api secara nyata, kebakaran yang dapat dipertanggungkan harus bersifat mendadak, harus ada sesuatu yang terbakar yang seharusnya tidak terbakar.

\footnotetext{
${ }^{19}$ Ibid, hlm. 89.

${ }^{20}$ Ibid.
} 
Permasalahan ini sebenarnya menjelaskan suatu fakta hukum dimana pembatalan sertipikat suatu hak yang menjadi objek jaminan suatu kredit tidak menjadi tanggungan resiko dari perusahaan asuransi dikarenakan bahwa biasanya terjadinya sengketa pembatalan sertifikat hak atas tanah adalah karena kelalaian debitur (perbuatan melawan hukum) ataupun kelalaian dari kreditur (telah melalui proses penelitian dan prinsip kehati-hatian sebelum dicairkannya kredit). Akan tetapi dalam putusan tersebut yang dinyatakan bersalah yaitu pihak Kantor Pertanahan Kota Padang yang telah lalai dalam proses penerbitan Hak Guna Bangunan tersebut. Sehingga perlu adanya suatu produk asuransi yang menanggung resiko terhadap hilangnya hak kebendaan yang diakibatkan kelalaian pihak ketiga.

Pada Putusan Pengadilan Negeri dengan Perkara Nomor. 27/PDT.G/2010/PN.PDG dalam pertimbangannya majelis hakim menyatakan bahwa penguasaan atas tanah terperkara oleh Penggugat dan sebagian tanah terperkara oleh Tergugat III adalah berdasarkan hukum karena keduanya adalah pembeli yang beritikad baik. Majelis Hakim kemudian menimbang bahwa kesalahan ini terjadi karena kelalaian dari Tergugat IV yaitu Kantor Pertanahan Kota Padang yang tidak teliti dalam penganganan administrasi pertanahan sehingga terjadinya tumpang tindih kepemilikan. Akan tetapi, majelis hakim memandang Hak Milik merupakan hak terkuat dan dilihat dari terbitnya sertifikat Hak Milik tersebut lebih dahulu daripada sertifikat Hak Guna Bangunan terperkara. Sehingga majelis hakim dalam putusannya memutuskan:

a. Mengabulkan gugatan penggugat sebahagian;

b. Menyatakan Akta Jual Beli Penggugat yang dilakukan didepan Pejabat Pembuat Akta Tanah Kotamadya Padang, Amawel Amin, SH, Notaris di Padang tanggal 22 Agustus 1978 dengan No. 192/B/1978 kuat dan berharga;

c. Menyatakan Sertifikat Hak Milik No. 2536, Gambar Situasi No. 779 tanggal 1 April 2009, Desa/Kelurahan Kurao Pagang, Kecamatan Nanggalo, Kota Padang atas nama Ramon Widjaja (Penggugat) secara sah, kuat dan berharga; 
d. Menyatakan Sertifikat Hak Guna Bangunan No. 209 atas Nama Buchari yang telah dijual kepada Tergugat III (Zainirman) tanggal 6 Februari 2004 yang terletak dikelurahak Kurao Pagang, Kecamatan Naggalo, Kota Padang tidak mempunyai kekuatan hukum;

e. Menyatakan Tergugat I, Terguguat II, Tergugat III, Tergugat IV sebagai Perbuatan Melawan Hukum (onrecht mattigedaad);

f. Membebankan Tergugat-Tergugat membayar ongkos perkara sebesar Rp. 1.796.000,- (satu juta tujuh ratus Sembilan puluh enam ribu rupiah).

Dari duduk kasus diatas poin yang sangat penting adalah bahwa Zainirman (Tergugat III) yang merupakan debitur merupakan pembeli yang beritikad baik dan dalam putusannya hal ini murni adalah kelalaian dari pihak Kantor Pertanahan Kota Padang. Dengan adanya putusan tersebut yang mana sebenarnya kemudian memberikan kerugian bagi Bank Nagari selaku pihak ketiga yang mana Hak Guna Bangunan terperkara merupakan suatu jaminan kredit pada bank Nagari tersebut sesuai dengan Surat Keputusan Kredit (SKK) tanggal 4 Maret 2005 Nomor: SR/11/STB/03-2005 dengan jenis Kredit Modal Kerja Multi Guna serta Perjanjian Kredit (PK) No.PK/010/STB/KMk-mg/03-2005/03-2008, tanggal 8 Maret.

Oleh karena itu perlu upaya perlawanan oleh bank Nagari selaku pemilik jaminan Hak Tanggungan atas tanah Hak Guna Bangunan terperkara untuk melakukan gugatan kembali terhadap Kantor Pertanahan Kota Padang atas kerugian yang timbul dari hilangnya Hak Tanggungan pada bank Nagari tersebut. hal ini didasarkan atas kelalaian dari Kantor Pertanahan Kota Padang dalam hal administrasi yang tidak hanya merugikan debitur namun juga merugikan pihak bank itu sendiri dan dalam tatanan hukum perdata hal ini merupakan perbuatan melawan hukum (onrecht mattigedaad) yang dalam Pasal 1365 KUHPerdata menyatakan bahwa tiap perbuatan melanggar hukum yang membawa kerugian kepada orang lain, mewajibkan orang karena salahnya menerbitkan kerugian itu, mengganti kerugian tersebut. lebih lanjut Pasal 1366 KUHPerdata menyebutkan bahwa setiap orang bertanggungjawab tidak saja untuk kerugian yang disebabkan karena perbuatannya, tetapi juga untuk kerugian yang disebabkan karena kelalaiannya itu atau kurang hati-hatinya. 
Dari Pasal 1365 KUHPerdata di atas dapat diketahui bahwa unsur-unsur dari perbuatan melawan hukum adalah: ${ }^{21}$

1. Adanya suatu perbuatan. Suatu perbuatan melawan hukum diawalai oleh suatu perbuatan dari si pelakunya.

2. Perbuatan tersebut melawan hukum.

3. Adanya kerugian bagi korban.

4. Adanya hubungan kausal antara perbuatan dengan kerugian.

Melihat dari hal tersebut di atas maka perlu adanya suatu upaya hukum yang ditempuh oleh bank Nagari atas kelalaian Kantor Pertanahan Kota Padang yang menimbulkan kerugian yang signifikan oleh Bank Nagari. Bentuk dari upaya hukum itu sendiri setelah dibatalkannya Hak Guna Bangunan yang berdampak hapusnya Hak Tanggungan dapat ditempuh dengan dua cara yaitu:

1. Upaya musyawarah atau perundingan kembali antara kreditur dan debitur mengenai dibatalkannya Hak Guna Bangunan yang dijadikan jaminan Hak Tanggungan. Artinya hal ini kembali pada klausul perjanjian pokok atau affirmative covenant dimana pada salah satu poinnya debitur harus segera memberitahu kepada kreditur tentang adanya kerusakan, kerugian atau kemusnahan atas jaminan yang diserahkan. ${ }^{22}$

Fungsi dari pemberitahuan mengenai kondisi jaminan tersebut pada dasarnya memungkinkan adanya suatu perundingan kembali jika ada terjadi kerusakan, kerugian maupun kemusnahan barang jaminan, hal ini juga merupakan prinsip kehati-hatian yang diterapkan oleh bank dalam mengantisipasi kerugian yang muncul jika suatu saat terjadi kredit bermasalah. Dengan berlandaskan Pasal 1338 Ayat (3) KUHPerdata yakni asas itikad baik dari debitur dalam hal Hak Guna Bangunan yang menjadi jaminan Hak Tanggungan dibatalkan haknya oleh Pengadilan Negeri untuk bersama-sama melakukan mediasi atau perundingan kembali antara kreditur dan debitur mengenai kondisi jaminan debitur, apakah dengan cara diberikan jaminan kebendaan yang baru oleh debitur

${ }^{21}$ Dikutip dari situs http://saytvankelsen.wordpress.com/ diakses pada tanggal 13 April 2016 pukul 11.00 WIB. $120-121$

${ }^{22}$ Sutarno, 2004, Aspek-aspek Hukum Perkreditan pada Bank, Alfabeta, Bandung, hlm. 
atau dengan memberikan jaminan borgtoch sebagai wujud dari itikad baik debitur terhadap konsistensinya dalam pelunasan utang piutangnya. Atau;

2. Pihak Bank dapat mengajukan gugatan secara perdata terhadap Kantor Pertanahan Kota Padang kepada Pengadilan Negeri sebagai bentuk dari perlindungan hukum bagi bank itu sendiri atas dasar adanya perbuatan melawan hukum pada Pasal 1365 KUHPerdata (Onrecht mattigedaad).

\section{Hubungan Hukum Antara Kreditur dan Debitur Setelah dibatalkannya Sertifikat Hak Guna Bangunan Sebagai Jaminan Hak Tanggungan}

Hak Tanggungan sebagai satu-satunya lembaga hak jaminan atas tanah untuk pelunasan utang tertentu mempunyai salah satu asas yaitu antara lain memberikan kedudukan yang diutamakan (preferent) kepada krediturnya. ${ }^{23}$ Hal ini berarti bahwa kreditor pemegang Hak Tanggungan mempunyai hak untuk didahulukan di dalam mendapatkan pelunasan atas piutangnya daripada krediturkreditur lainnya atas hasil penjualan benda yang dibebani Hak Tanggungan tersebut.

Secara preventif, bank dilarang mengobral dana atau bersikap "murah hati" kepada nasabah, oleh karenanya penyaluran kredit harus disertai agunan lengkap dengan perjanjian untuk menjual barang agunan atas kekuasaan kreditor. Dengan janji tersebut bank selaku kreditor dapat menjual langsung barang jaminan (parate executie) dengan bantuan Kantor Lelang Negara (KLN) tanpa harus meminta izin (fiat) Pengadilan Negeri. ${ }^{24}$ Ketentuan ini kemudian dikukuhkan dalam Pasal 11 Ayat (2) huruf e UUHT.

Konsekuensi hukum akibat pembatalan Hak Guna Bangunan dalam kasus putusan Pengadilan Negeri tersebut yaitu hilangnya hak atas tanah itu sendiri. Jika hak atas tanah yang menjadi objek Hak Tanggungan hilang/hapus maka sesuai dengan Pasal 18 UUHT maka hapuslah juga Hak Tanggungan tersebut. hal ini tentu memberikan kerugian yang besar kepada bank dan sekaligus membuat bank harus siap-siap menanggung resiko terjadinya kredit bermasalah nantinya.

Namun berkenaan dengan pembatalan sertifikat merupakan suatu proses yang tidak gampang dan tentunya harus melalui beberapa prosedur-prosedur yang

\footnotetext{
${ }^{23}$ Adrian Sutedi, Op. cit, hlm. 56.

${ }^{24}$ Ibid, hlm. 106.
} 
telah ditetapkan oleh Badan Pertanahan Nasional itu sendiri. Dalam Pasal 1 angka 14 Peraturan Meteri Negara Agraria/Kepala Badan Pertanahan Nasional Nomor 9 Tahun 1999 Tentang Tata Cara Pemberian Dan Pembatalan Hak Atas Tanah Negara Dan Hak Pengelolaan (Selanjutnya disingkat Permenag No. 9 Tahun 1999) menyebutkan bahwa pembatalan hak atas tanah adalah pembatalan keputusan pemberian suatu hak atas tanah atau sertipikat hak atas tanah karena keputusan tersebut mengandung cacad hukum administrasi dalam penerbitannya atau untuk melaksanakan putusan pengadilan yang telah memperoleh kekuatan hukum tetap. Jika dilihat pengertian diatas maka kasus ini merupakan termasuk pembatalan hak yang dimaksud karena mengandung cacad hukum administrasi dalam penerbitannya.

Lebih lanjut mengenai tata cara pembatalan hak atas tanah dalam Pasal 104 Permenag No. 9 Tahun 1999 yang berbunyi:

(1)Pembatalan hak atas tanah meliputi pembatalan keputusan pemberian hak, sertipikat hak atas tanah keputusan pemberian hak dalam rangka pengaturan penguasaan tanah.

(2)Pembatalan hak atas tanah sebagaimana dimaksud pada ayat (1) diterbitkan karena terdapat cacat hukum administrasi dalam penerbitan keputusan pemberian dan/atau sertipikat hak atas tanahnya atau melaksanakan putusan pengadilan yang telah memperoleh kekuatan hukum tetap.

Pasal 106 Permenag No. 9 Tahun 1999 berbunyi:

(1)Keputusan pembatalan hak atas tanah karena cacad hukum administratif dalam penerbitannya, dapat dilakukan karena permohonan yang berkepentingan atau oleh Pejabat yang berwenang tanpa permohonan.

(2)Permohonan pembatalanhak dapat diajukan atau langsung kepada Menteri atau Pejabat yang ditunjuk atau melalui Kepala Kantor Pertanahan.

Adapun cacad hukum administratif yang dimaksud dalam Pasal 106 di atas berdasarkan Pasal 107 Permenag No. 9 Tahun 1999 yaitu kesalahan prosedur, kesalahan penerapan peraturan perundang-undangan, kesalahan subjek hak, kesalahan objek hak, kesalahan jenis hak, terdapat tumpang tindih hak atas tanah, 
data yuridis dan data fisik tidak benar, atau kesalahan lain yang bersifat hukum administratif.

Berkaitan dengan kasus perkara yang merupakan putusan Pengadilan yang telah memiliki kekuatan hukum yang tetap, oleh karenanya pembatalan hak nya adalah pembatalan hak atas tanah karena melaksanakan putusan Pengadilan yang telah memperoleh kekuatan hukum tetap. maka menurut Pasal 124 Permenag No. 9 Tahun 1999, menyatakan bahwa:

(1)Keputusan pembatalan hak atas tanah karena melaksanakan putusan pengadilan yangtelah memperoleh kekuatan hukum tetap diterbitkan atas permohonan yang berkepentingan.

(2)Amar putusan pengadilan yang telah memperoleh kekuatan hukum tetap meliputi dinyatakan batal atau tidak mempunyai kekuatan hukum atau yang pada intinya sama dengan itu.

Selanjutnya diatur dari Pasal 124 hingga Pasal 133 Permenag No. 9 Tahun 1999 tentang teknis pembatalan hak atas tanahnya. Diketahui bahwa dalam hal pembatalan hak harus dilakukan dengan penerbitan surat keputusan pembatalan hak itu sendiri yang ditujukan kepada Menteri ataupun melalui Kantor Pertanahan Kabupaten/Kota. Dengan adanya diatur mengenai teknis pembatalan hak atas tanah tersebut, maka hak yang oleh karena Putusan Pengadilan dibatalkan dengan tidak memiliki kekuatan hukum belum batal sampai pada diterbitkannya surat keputusan mengenai pembatalan hak atas tanah yaitu Hak Guna Bangunan itu sendiri.

\section{Perlindungan Hukum Kreditur Setelah Dibatalkannya Sertifikat Hak Guna Bangunan Yang Dijadikan Objek Hak Tanggungan}

Sifat dari jaminan Hak Tanggungan adalah merupakan ikutan (accessoir) pada perjanjian yang menimbulkan hubungan hukum utang piutang (perjanjian kredit). ${ }^{25}$ Dengan demikian, hapusnya Hak Tanggungan tergantung pada perjanjian pokoknya, yaitu utang yang dijamin pelunasannya tersebut. Namun, melihat dari kuatnya kedudukan Hak Tanggungan dalam hukum yang memberikan hak eksekutorial serta memberikan hak istimewa atau hak didahulukan pelunasannya bagi kreditur terhadap kreditur lainnya dengan

\footnotetext{
${ }^{25}$ Adrian Sutedi, Op. cit, hlm. 56.
} 
langsung menjual dengan pelelangan umum apabila debitur wanprestasi. Sehingga menurut penulis hapusnya hak tanggungan disebabkan permasalahan dalam kasus ini berdampak pada hilangnya hak eksekutorial dan hak istimewa terhadap kreditur dalam hal pelunasan utang merupakan kerugian dan suatu permasalahan hukum. Karena dengan demikian dapat mempengaruhi atau membuka besarnya resiko bermasalahnya kredit yang dapat menyebabkan tidak sehatnya perkonomian bank.

Berlakunya jaminan secara umum tidak merupakan jaminan bagi bank untuk mendapatkan pelunasan terhadap kredit bermasalah. Hal ini bisa terjadi apakah debitur tidak memiliki kemampuan finansial selain dari Hak Guna Bangunan tersebut, atau bisa saja debitur menggantungkan usahanya terhadap bangunan dengan Hak Guna Bangunan tersebut yang mana ketika hak tersebut hilang maka hilanglah juga kemampuan ekonomi debitur dalam melunasi hutangnya. Oleh sebab itu perlu dikaji mengenai bentuk perlindungan hukum lain secara perdata jika terjadi hal-hal sedemikian rupa dalam mengambil pelunasan kredit tersebut.

Perlindungan hukum terhadap kreditur adalah segala upaya yang menjamin adanya kepastian hukum untuk memberi perlindungan kepada hak-hak kreditur dalam pemberian kredit sehingga tercapainya keadilan baik yang terdapat dalam peraturan hukum maupun dalam perjanjian-perjanjian antara kreditur dengan debitur. ${ }^{26}$ Perlindungan hukum disini bertujuan untuk memperkecil resiko bahkan sampai menghilangkan resiko yang mungkin timbul maupun yang sudah timbul/terjadi.

Jika dikaji secara teoritis maka apa yang dimaksud dengan perlindungan hukum itu sendiri yaitu yaitu upaya atau bentuk pelayanan yang diberikan oleh hukum kepada subjek hukum serta hal-hal yang menjadi objek yang dilindungi. ${ }^{27}$ Pada dasarnya, peralihan kedudukan kreditur dari kreditur preferen menjadi kreditur konkuren tetap memberikan perlindungan hukum, yaitu perlindungan hukum secara umum pada Pasal 1131 KUHPerdata dimana segala harta kekayaan debitur menjadi jaminan pelunasan utang piutang apabila terjadi wanprestasi.

${ }^{26}$ Titik Triwulan Tutik, 2008, Hukum Perdata dalam Sistim Hukum Nasional, Kencana Prenada Media Group, Surabaya, hlm. 358.

${ }^{27}$ Salim HS dan Erlies Septiana Nurhani, Op. cit, hlm. 262. 
Akan tetapi, dalam konteks ini bentuk perlindungan hukum yang diberikan juga mengalami degradasi atau melemah secara yuridis. Karena jika melihat dari resiko yang akan ditanggung oleh bank adalah tidak sebanding dengan kehilangan hak istimewa terhadap perlakuan objek Hak Tanggungan. Dengan demikian bentuk perlindungan hukum yang bisa ditempuh dalam permasalahan ini adalah perlindungan hukum preventif dan perlindungan hukum refresif.

Perlindungan hukum preventif itu sendiri adalah perlindungan hukum yang sifatnya pencegahan. Artinya setelah adanya putusan Pengadilan yang membatalkan sertifikat Hak Guna Bangunan yang dibebani Hak Tanggungan tersebut, pada prinsipnya perjanjian kredit masih berlaku, karena Hak Tanggungan itu sendiri sifatnya adalah perjanjian tambahan. Sehingga tidak dapat dikatakan kredit tersebut langsung bermasalah, akan tetapi resiko hilangnya Hak Tanggungan ini akan berdampak dalam pelunasan utang piutang jika terjadi kredit bermasalah. Karenanya perlu suatu pencegahan sebagai upaya yang memberikan perlindungan hukum bagi kreditur yaitu dengan berlandaskan Pasal 1338 Ayat (3) KUHPerdata yaitu asas itikad baik untuk dilakukannya mediasi antara kedua belah pihak mengenai benda jaminan tersebut, apakah dengan adanya pemberian jaminan atau agunan baru oleh pihak debitur kepada kreditur atau juga dengan penjaminan secara borgtoch.

Bentuk perlindungan hukum lain yang dapat digunakan adalah dengan menggunakan perlindungan hukum yang represif, karena bertujuan untuk menyelesaikan sengketa antara kreditur dengan debitur jika terjadi kredit bermasalah dalam hal perjanjian Hak Tanggungan yang disebabkan oleh hapusnya hak atas tanah Hak Guna Bangunan yang dibebankan Hak Tanggungan tersebut. Dimana pihak debitur harus berkewajiban untuk melunasi sisa-sisa hutang yang masih ada kepada kreditur, sehingga kreditur berhak melakukan eksekusi terhadap objek Hak Tanggungan si debitur untuk mengambil keuntungan dan melunasi hutang debitur. Dalam perlindungan hukum refresif ini memberikan makna bahwa perlindungan hukum ini digunakan ketika telah terjadi kredit bermasalah sedangkan agunan Hak Tanggungan itu sendiri telah hapus. Perlindungan hukum refresif ini dapat diwujudkan melalui mediasi (non litigasi) maupun dengan melalui jalur litigasi (lembaga Pengadilan). 
Pada prinsipnya upaya yang dilakukan dalam penyelesaian sengketa perbankan ini telah diakomodir dengan adanya mediasi perbankan. Sebelum adanya lembaga Otoritas Jasa Keuangan (OJK), mediasi perbankan diatur dalam Peraturan Bank Indonesia No. 8/5/PBI/2006 tentang Mediasi Perbankan sebagaimana diubah dengan Peraturan Bank Indonesia No. 10/1/PBI/2008, sedangkan setelah OJK dibentuk maka berlaku Peraturan Otoritas Jasa Keuangan Nomor. 1/POJK.07/2014 Tentang Lembaga Alternatif Penyelesaian Sengketa di Sektor Jasa Keuangan. Akan tetapi Peraturan Otoritas Jasa Keuangan ini tidak mencabut Peraturan Bank Indonesia tentang Mediasi Perbankan tersebut. Namun jika dilihat lebih mendalam mengenai kriteria penyelesaian sengketa perbankan yang difasilitasi oleh OJK maupun Mediasi perbankan dalam Peraturan Bank Indonesia sebelumnya merupakan penyelesaian sengketa apabila konsumen atau nasabah yang dirugikan oleh pihak pelaku usaha jasa keuangan, dalam kasus ini adalah pihak bank.

Oleh sebab itu sangatlah tidak dapat dijadikan dasar penyelesaian sengketa secara refresif dalam kasus ini, karena sejatinya pihak banklah yang dirugikan dengan adanya kredit bermasalah yang awalnya muncul dari resiko hilangnya Hak Tanggungan tersebut. Dalam PBI mengenai mediasi perbankan dan POJK No. 1 Tahun 2014 dijelaskan bahwa penyelesaian sengketa didasarkan oleh adanya pengaduan dari konsumen kepada Bank Indonesia dalam hal berlakunya PBI Mediasi Perbankan dan kepada OJK dalam hal telah diberlakukannya POJK No. 1 Tahun 2014.

Oleh karenanya langkah atau upaya perlindungan hukum yang dapat diberikan adalah dengan upaya Mediasi dengan mempertimbangkan Analisa Resiko Kredit oleh Komite Pemantau Resiko pada lembaga Bank Nagari tersebut serta dengan melihat asas positive covenant bagi bank. Jika upaya hukum mediasi tidak tercapai, maka perlindungan yang diberikan adalah dengan Pasal 1131 KUHPerdata dimana dilakukan sita umum atas kekayaan debitur jika terjadi kredit bermasalah dengan kualitas kredit macet. 


\section{PENUTUP}

\section{A. Kesimpulan}

Dari hasil pembahasan di atas dapat disimpulkan beberapa permasalahan yaitu:

1. Upaya hukum yang ditempuh untuk mengantisipasi kredit bermasalah yaitu dengan menerapkan prinsip kehati-hatian yang direalisasikan dalam prinsip 5C serta dengan mengasuransikan objek jaminan Hak Tanggungan. Sementara upaya hukum yang dilakukan pasca putusan perkara tersebut di atas adalah Pertama, yaitu dengan melakukan perundingan kembali dengan melihat affirmative covenant pada perjanjian kredit serta berasaskan itikad baik untuk dilakukannya musyawarah atau perundingan kembali terhadap permasalahan jaminan Hak Tanggungan yang telah hapus, apakah dengan pemberian jaminan kebendaan tambahan atau dengan borgtoch. Kedua, yaitu dengan mengajukan gugatan secara perdata oleh Kreditur yaitu pihak bank atas kerugian yang timbul dikarenakan perbuatan melawan hukum dari pihak Kantor Pertanahan Kota Padang.

2. Hubungan hukum antara kreditur dan debitur setelah dibatalkannya sertifikat Hak Guna Bangunan yang dijadikan Hak Tanggungan oleh Pengadilan Negeri pada dasarnya masih terikat hak dan kewajiban serta berlaku perjanjian pokok utang piutang, karena Hak Tanggungan hanya bersifat perjanjian tambahan saja, namun yang berubah adalah kedudukan dari kreditur preferen menjadi kreditur konkuren. Akan tetapi, pembatalan sertifikat pada dasarnya tidak serta merta batal ketika dibatalkan oleh pengadilan, hal ini tentu harus suatu keputusan dari Menteri mengenai pembatalan hak atas tanah dimana diatur lebih jauh dalam Permenag No. 9 Tahun 1999 tentang Tata Cara Pemberian dan Pembatalan Hak Atas Tanah Negara dan Hak Pengelolaan.

3. Berlakunya jaminan secara umum pada prinsipnya memberikan suatu perlindungan hukum, hanya saja terjadi penurunan atau pelemahan dari perlindungan hukum yang semula memberikan keutamaan bagi kreditur menjadi perlindungan hukum yang mencakup secara umum saja. Oleh 
sebab itu perlindungan hukum yang diberikan kepada kreditur adalah berupa perlindungan hukum preventif yang mana hal ini dilakukan untuk mencegah terjadinya kredit bermasalah setelah Hak Tanggungan tersebut hapus yaitu dapat diwujudkan dengan adanya madiasi antara kreditur dengan debitur berkenaan dengan hapusnya Hak Guna Bangunan yang dijadikan jaminan hak tanggungan. Kemudian juga dapat diberikan perlindungan hukum refresif dimana posisi ini digunakan apabila telah terjadi sengketa perbankan yaitu kredit bermasalah sementara kreditur tidak memiliki agunan yang dapat dijadikan pelunasan secara mudah dan pasti yaitu dengan melakukan sita umum jika terjadi kredit macet sesuai dengan Pasal 1131 KUHPerdata.

\section{B. Saran}

1. Sangat penting bagi pihak perbankan saat ini untuk lebih memikirkan segala resiko yang tidak diduga-duga terhadap jaminan yang diserahkan oleh debitur sebagai pelunasan kredit dengan cara mempertegas didalam klausul-klausul dalam perjanjian kredit, seperti apabila terjadi sesuatu terhadap jaminan yang diserahkan oleh debitur seperti kasus ini, pihak bank berhak meminta kepada debitur jaminan baru yang dapat berupa kebendaan ataupun borgtoch sebagai wujud dari prinsip kehati-hatian bagi pihak bank, sehingga dengan adanya klausul tersebut, bank mendapatkan suatu kepastian hukum mengenai pelunasan utang piutangnya jika suatu saat terjadi kredit bermasalah dan sebagai bentuk dari itikad baik debitur. Kemudian juga harusnya ada asuransi atas tanah yang diatasnya tidak terdapat bangunan sehingga hal ini dapat memberikan antisipasi resiko terhadap musnahnya suatu tanahnya.

2. Perlunya suatu kepastian hukum dimana dalam hal pembatalan hak atas tanah harus ada suatu keputusan yang kuat dari Menteri setelah adanya putusan Pengadilan tersebut. Sehingga bank tidak perlu khawatir karena pada prinsipnya tanpa adanya keputusan pembatalan hak dari Menteri Agraria maka bank masih tetap memiliki hak preferent atas Hak Guna Bangunan tersebut. 
3. Perlu suatu badan atau lembaga yang memberikan perlindungan hukum khusus kepada bank yang mengalami kerugian yang disebabkan oleh pihak ketiga yang dapat diwujudkan dengan dibuatnya mediasi khusus terhadap kerugian yang ditanggung oleh bank yang disebabkan pihak ketiga sebagai langkah hukum preventif yaitu mencegah terjadinya kredit bermasalah jika kreditur kehilangan Hak Tanggungan atas dasar kesalahan pihak ketiga. 


\section{A. Buku-buku}

\section{DAFTAR PUSTAKA}

Achmad Ali, 2007, Menguak Teori Hukum (legal theory) dan Teori Peradilan (Judicialprudence) termasuk Interpretasi Undang-Undang (Legisprudence), Kencana, Jakarta.

Adrian Sutedi, 2012, Hukum Hak Tanggungan, Sinar Grafika, Cetakan Kedua, Jakarta.

Boedi Harsono, 2005, Hukum Agraria Indonesia (sejarah Pembentukan Undang-Undang Pokok Agraria, Isi dan Pelaksanaannya), Djambatan, Jakarta.

Djaja S. Meliala, Perkembangan Hukum Perdata tentang Benda dan Hukum Perikatan, Cetakan I, Nuansa Aulia, Bandung.

Djoni S. Gazali dan Rachadi Usman, 2010, Hukum Perbankan, Sinar Grafika, Jakarta.

Eli Wuria dewi, Mudahnya Mengurus Sertifikat Tanah \& Segala Perizinannya, Buku Pintar, Yogyakarta.

H. Ali Achmad Chomzah, 2002, Hukum Pertanahan, Prestasi Pustaka, Jakarta.

H. R. Daeng Naja, 2005, Hukum Kredit dan Bank Garansi, PT. Citra Aditya Bakti, Bandung.

Habib Adjie, 1999, Hak Tanggungan Sebagai Lembaga Jaminan Atas Tanah, CV. Mandar Maju, Bandung.

J. Satrio, 1993, Hukum Perjanjian, Citra Aditya Bakti, Bandung.

Kartini Muljadi dan Gunawan Widjaja, 2005, Seri Hukum Harta Kekayaan : Hak Tanggungan, Kencana, Jakarta.

Kartini Muljadi dan Gunawan Widjaja, 2002, Perikatan Yang Lahir Dari Perjanjian, PT. Rajagrafindo Persada, Jakarta.

Kasmir, 2014, Dasar-dasar Perbankan, PT. Rajagrafindo Persada, Jakarta.

Lukman Santoso, 2012, Hukum Perjanjian Kontrak, Cetakan Pertama, Cakrawala, Yogyakarta.

M. Bahsan, 2007, Hukum Jaminan dan Jaminan Kredit Perbankan Indonesia, PT. Rajagrafindo Persada Jakarta.

Maria Alfons, 2010, Implementasi Perlindungan Indikasi Geografis atas Produk-Produk Masyarakt Lokal dalam Perspektif Hak Kekayaan Intelektual, Universitas Brawijaya, Malang.

Otje Salman dan Anton F. Susanto, 2004, Teori Hukum, Mengingat, Mengumpulkan dan Membuka Kembali, Rafika Aditama Press, Jakarta.

Pjillipus M. Hadjon, 1987, Perlindungan Hukum Bagi Rakyat Indonesia, PT. Bina Ilmu, Surabaya.

Purwahid Patrik dan Kashadi, Hukum Jaminan Edisi Revisi dengan UUHT, Semarang. 
R. Wirjono Prodjodikoro, 2000 Asas - Asas Hukum Perjanjian, Mandar Maju, Bandung.

Rachmadi Usman, 2008, Hukum Jaminan Keperdataan, Sinar Grafika, Jakarta.

Salim HS dan Erlies Septiana Nurhani, 2013, ,Penerapan Teori Hukum Pada Penelitian Tesis dan Desertasi, PT. Rajagrafindo Persada, Jakarta.

Salim HS, 2004, Perkembangan Hukum Jaminan di Indonesiai, PT. Rajagrafindo Persada, Jakarta.

Satjipto Rahardjo, 2000, Ilmu Hukum, PT. Citra Aditya Bakti, Bandung.

Sjaifurrachman, 2011, Aspek Pertanggungjawaban Notaris dalam Pembuatan Akta, Pernerbit: Mandar Maju, Bandung.

Subekti, 2005, Hukum Perjanjian, Intermasa, Jakarta. 1982, Pokok - Pokok Hukum Perdata, cetakan XVI, PT. Intermasa, Jakarta.

Sutarno, 2004, Aspek-aspek Hukum Perkreditan pada Bank, Alfabeta, Bandung.

Titik Triwulan Tutik, 2008, Hukum Perdata dalam Sistim Hukum Nasional, Kencana Prenada Media Group, Surabaya.

Thomas Suyatno, dkk, 2003, Kelembagaan Perbankan, PT. Gramedia Pustaka Utama, Edisi Ketiga, Jakarta.

Urip Santoso, 2010, Pendaftaran dan Peralihan Hak atas Tanah, Kencana, Jakarta.

\section{B. Peraturan Perundang-undangan}

Undang-Undang Dasar Negara Republik Indonesia Tahun 1945.

Undang-Undang Nomor 5 Tahun 1960 tentang Peraturan Pokok-Pokok Agraria.

Undang-Undang Nomor 4 Tahun 1996 tentang Hak Tanggungan atas Tanah Beserta Benda-Benda yang Berkaitan dengan Tanah.

Undang-Undang Nomor 10 Tahun 1998 tentang Perbankan atas Perubahan Undang-Undang Nomor 7 Tahun 1992.

Peraturan Pemerintah Nomor 24 Tahun 1997 tentang Pendaftaran Tanah.

Peratauran Menteri Negara Agraria Nomor 5 Tahun 1996 tentang Pendaftaran Hak Tanggungan.

Peraturan Meteri Negara Agraria/Kepala Badan Pertanahan Nasional Nomor

9 Tahun 1999 Tentang Tata Cara Pemberian Dan Pembatalan Hak Atas Tanah Negara Dan Hak Pengelolaan.

\section{Internet}

http://www.banknagari.co.id/

http://id.wikipedia.org/uji_tuntas 
http://iwanvictorleonardo.wordpress.com/2010/06/09/cara-penyelesaiankredit-bermasalah/ https://id.wikipedia.org/wiki/kreditur http://www.landasanteori.com/2015/10/pengertian-prinsip-kehati-hatiandalam.html

http://saytvankelsen.wordpress.com/ 